\title{
BROTH DEPENDING PRODUCTION OF EXTRACELLULAR ENZYMES BY ENTEROBACTERIA ISOLATED FROM DAIRY FOOD (SERBIAN CHEESE)
}

\author{
Katarina G. Mladenović *1, Mirjana Ž. Grujović1, Violeta D. Jakovljević², \\ LJiljana R. Čomić1 \\ ${ }^{1}$ University of Kragujevac, Faculty of Science, Department of Biology and Ecology, \\ Radoja Domanovića 12, 34000 Kragujevac, Serbia \\ ${ }^{2}$ State University of Novi Pazar, Department of Biomedical Science, \\ Vuka Karadžića bb, 36300 Novi Pazar, Serbia \\ *Corresponding author; E-mail: katarina.mladenovic@pmf.kg.ac.rs
}

(Received January 17, 2020; Accepted May 1, 2020)

\begin{abstract}
In this paper, we investigated, for the first time, the enzyme activity of enterobacteria from cheese from Southeastern Serbia (Sokobanja), which was produced in a traditional way. The tested bacteria were selected from the spring, summer, and autumn collections and grown in two different broths. The enzyme activity was investigated in the two broths and measured using spectrophotometry method. It was concluded that there were differences in the amount of extracellular enzymes depending on the broths. A statistically significant rise in the amount of enzymes was demonstrated in Tripton soy broth. Bacteria in cheese do not possess the ability to produce extracellular enzymes in large amounts. Therefore, they do not change the organoleptic characteristics of the cheese. There is a possibility that if they are found outside their natural environment (cheese), without interactions with antagonists, they may exhibit stronger enzyme activity.
\end{abstract}

Keywords: extracellular enzyme, enterobacteria, cheese, dairy food.

\section{INTRODUCTION}

Gram-negative bacteria release proteins (extracellular enzymes) into the growth medium (PUGSLEY et al., 1986). One of the most interesting aspects of secretion in gram-negative bacteria is how the protein crosses the membrane (EISELE et al., 1972). The characterization of extracellular bacterial enzymes is very important since they have a role in causing infections, cell cytotoxicity, and their possible applications in biotechnology (MARTY et al., 2002). Extracellular enzymes of the pathogen increase its virulence (SHARMA and TIWARI, 2005). 
It is well-known that bacteria from family Enterobacteriaceae could affect the organoleptic properties of milk products (HERVERT et al., 2017). Serratia spp., one of the members of the fam. Enterobacteriaceae possess the capacity to produce extracellular enzymes: amylase, protease, lipase, etc. (SHARMA and TIWARI, 2005). Moreover, according to HINES et al. (1988), Serratia marcescens can secret several proteins extracellularly. Starch-debranching pullulanase, produced by some strains of Klebsiella pneumoniae is one example of a protein secreted by gram-negative bacteria (EISELE et al., 1972). One of the studies was focused on examining DNA exonuclease from Escherichia coli and their roles in metabolism (LOVETT, 2011). Extracellular hydrolytic enzymes such as amylases, proteases, lipases, pullulanase, and DNases, xylanases, have potential use in various areas such as the food industry, feed additive, biomedical sciences and chemical industries (SANCHEZ-PORRO et al., 2003). Twothirds of industrially produced proteases are from microbiological sources. One of the studies was focused on the screening of the protease enzyme produced by bacteria collected from the cheese isolated at Dilla University (Ethiopia). All of the above isolates are potential sources of proteolytic enzymes that can be used for industrial purposes (ALEMU, 2015).

The aim of this paper was to evaluate and quantify the enzymes of bacteria isolated from cheese produced in traditionally way in Sokobanja (Southeastern Serbia) and determine the dependence of the amount of enzymes on the substrate where the bacteria were grown.

\section{MATERIALS AND METHODS}

\section{Cheese production and sampling}

The tested cheese was produced in countryside households around Sokobanja, Southeastern Serbia, by using the traditional method. Fresh, processed, and unpasteurized cow's milk was filtered after milking, and then heated to the temperature of $30-40^{\circ} \mathrm{C}$. The quantity of added salt was about 6-8\% of the cheese weight. Three different samples of cheese were used (300 $\mathrm{g}$ of each of them). Each sample was collected from a different household in spring, summer, and autumn. Samples were aseptically transported to the microbiology laboratory at the Department of Biology and Ecology, University of Kragujevac (MLADENOVIĆ et al., 2018a).

\section{Microorganisms and broths used in experiment}

Member of the fam. Enterobacteriaceae were found in cheese from Sokobanja. Their biochemical characteristics and identification were described in (MLADENOVIĆ et al., 2018a; 2018b). Bacteria strains which were used for determining enzymes activity: $K$. oxitoca KGPMF 1, KGPMF 2, KGPMF 3, KGPMF 7, K. ornithinolytica KGPMF 8, K. pneumoniae KGPMF 10, KGPMF 11, KGPMF 12, E. coli KGPMF 14, KGPMF 16, KGPMF 21, KGPMF 24, S. odorifera KGPMF 18, S. marcescens biogp 1 KGPMF 19. The collection of identified bacterial species was kept in a $20 \%$ glycerol/medium mixture at $-80^{\circ} \mathrm{C}$ at the Faculty of Science, University of Kragujevac (KGPMF).

Broths used for growing were chosen due to their various compositions. Mueller Hinton broth (MH) (Torlak, Serbia) contained casein hydrolyzate acidic, meat extract, starch, while Tripton soy broth (TSB) (Torlak, Serbia) contained peptone from casein Torlak, peptone soybean, dextrose, sodium chloride, potassium hydrogen phosphate.

\section{Production of fermentation liquids of enterobacteria}

To investigate the enzymatic activity of enterobacteria, it is necessary to obtain fermentation liquids of the bacteria. In $10 \mathrm{ml}$ of TSB, $100 \mu \mathrm{l}$ of overnight bacterial culture was 
inoculated $\left(10^{8}-10^{9} \mathrm{CFU} / \mathrm{ml}\right) .10 \mathrm{ml}$ of $\mathrm{MH}$ was inoculated in the same way. Inoculated broths were incubated $24 \mathrm{~h}$ at $37^{\circ} \mathrm{C}$. After the incubation, samples were centrifuged at 10.000 $\mathrm{rpm}$ for $30 \mathrm{~min}$ at $4^{\circ} \mathrm{C}$. Then, the supernatant, which represented the fermentation liquid, was separated. Fermentation liquid was kept in the refrigerator at $4^{\circ} \mathrm{C}$ until the experiment was performed.

\section{Determination of acid and alkaline invertase activity}

Invertase enzyme activity was determined by SUMNER and HOWELL (1935). To determine the activity of alkaline invertase in the fermentation liquid of the bacteria, it is necessary to prepare a reaction mixture containing $0.5 \mathrm{ml}$ of crude enzyme extract, $0.5 \mathrm{ml}$ of $0.02 \mathrm{~mol} / \mathrm{l}$ phosphate buffer ( $\mathrm{pH} \mathrm{8.0)}$ and $1 \mathrm{ml}$ of $1 \%(\mathrm{w} / \mathrm{v}))$ sucrose. The contents of the tube (sample) were mixed and incubated in a water bath at $37^{\circ} \mathrm{C}$ for $15 \mathrm{~min}$. In the second control tube, all the ingredients were added as in the test tube, and that tube was placed in the ice until the incubation of the test was completed. $1 \mathrm{ml}$ of the contents of both tubes were taken and 2 $\mathrm{ml}$ of the dinitrosalicyl reagent were added. The test tubes were incubated at $100^{\circ} \mathrm{C}$ for $5 \mathrm{~min}$. The tubes were cooled at room temperature and then the amount of liberated reducing sugars was spectrophotometrically determined at $540 \mathrm{~nm}$ (MILLER, 1959). The enzymatic activity of acid invertase was determined in the same way in a reaction mixture containing $0.5 \mathrm{ml}$ of crude enzyme extract, $0.5 \mathrm{ml} 0.01 \mathrm{~mol} / \mathrm{l}$ sodium acetate buffer (pH 4.5), and $1 \mathrm{ml}$ of $1 \%(\mathrm{w} / \mathrm{v})$ sucrose.

To construct a standard curve, it was necessary to make a $1 \mathrm{mg} / \mathrm{ml}$ solution of $5.56 \mathrm{x}$ $10^{-3} \mathrm{~mol} / \mathrm{l}$ glucose standard (Sigma Aldrich). 0.05, 0.10, 0.20, 0.30, 0.40, and $0.50 \mathrm{ml}$ of standard glucose solution were measured into six tubes and the tubes were filled up with distilled water to $1 \mathrm{ml}$. As a blank standard, $1 \mathrm{ml}$ of water was taken. The contents of the tubes were mixed and the tubes were incubated at $55^{\circ} \mathrm{C}$ for $20 \mathrm{~min}$. The further procedure was the same as the one for determining invertase activity.

The invertase activity unit (IU) is defined as the amount of enzyme which catalyzes the production of $1 \mu \mathrm{mol}$ of glucose per minute at $37^{\circ} \mathrm{C}$.

Unit of enzymatic activity:

$$
\mathrm{IU} / \mathrm{ml}=\frac{(\mu \mathrm{mol} \text { glucose })(\mathrm{df})}{(20)(0.5)(2)}
$$

where df - dilution factor, 20 - incubation time ( $\mathrm{min}), 0.5$ - volume enzyme extract $(\mathrm{ml}), 2$ conversion factor of $1 \mu \mathrm{mol}$ of sucrose which hydrolyzes on glucose and fructose.

\section{Determination of alkaline phosphatase activity}

The enzymatic activity of alkaline phosphatase was determined based on the amount of inorganic phosphorus using Allen's method (ALLEN, 1940). Enzymatic activity was measured in a reaction mixture containing $1 \mathrm{ml}$ of glycol buffer $(\mathrm{pH} 9.0)$ with $\mathrm{Mg}^{2+}, 1 \mathrm{ml}$ of enzyme extract, and $1 \mathrm{ml}$ of $\beta$-glycerophosphate (substrate). The tubes containing the reaction mixture were incubated at $37^{\circ} \mathrm{C}$ for $30 \mathrm{~min}$. After the incubation, the enzyme reaction was interrupted with the addition of $3 \mathrm{ml}$ of $10 \%$ TCA (trichloroacetic acid). The tubes were placed in ice for 15 minutes after which the contents of the tubes were filtered and the filtrate was collected. Control tubes were prepared in the same way, but without incubation, TCA was immediately added, and the tubes were held in ice for $15 \mathrm{~min}$ and filtered. In order to determine the concentration of phosphorus in the sample, Allen's reaction was performed. 1 $\mathrm{ml}$ of the filtrate of the test and control tube were poured into two tubes, as well as $0.4 \mathrm{ml}$ of amide (amidol), $0.4 \mathrm{ml}$ of $60 \%$ PCA (perchloric acid), $0.2 \mathrm{ml}$ of $\mathrm{NH}_{4}$-molybdate and $3 \mathrm{ml}$ of distilled water. The tubes were incubated at room temperature for $11 \mathrm{~min}$. At the same time, a series of dilutions of the standard phosphorus solution were prepared and the above procedure 
was repeated, which served to construct a standard phosphorus curve. The absorbance solution was measured at $720 \mathrm{~nm}$.

Unit of enzymatic activity:

$$
\mathrm{IU} / \mathrm{ml}=\frac{(\mu \mathrm{mol} \text { phosphorus })(6)(\mathrm{df})}{(1)(30)(5)}
$$

where 6 -volume of the reaction mixture $(\mathrm{ml})$, df - dilution factor, 1 - volume of enzyme extract (ml), 30 - incubation time (min), 5 - volume taken for colorimetric determination (ml).

\section{Determination of alkaline protease activity}

The proteolytic activity of the fermentation liquid was determined based on the presence of enzymes in $1 \mathrm{ml}$ of the liquid medium by the Anson method (Anson, 1938), based on the amount of tyrosine liberated by the hydrolysis of casein under the action of proteolytic enzymes. The proteolytic activity of the fermentation liquid was determined as follows: in one tube, $1 \mathrm{ml}$ of fermentation fluid was added, while in another $5 \mathrm{ml}$ of $2 \%$ (w/v) solution of casein. Both tubes were heated in a water bath at $37^{\circ} \mathrm{C}$ for $15 \mathrm{~min}$. After that, $2 \mathrm{ml}$ of heated casein in a test tube with a fermentation liquid (test), were mixed and returned to incubate for another $10 \mathrm{~min}$. The enzyme reaction was stopped by the addition of $5 \mathrm{ml}$ of cold $5 \%(\mathrm{w} / \mathrm{v})$ trichloroacetic acid (TCA). The mixture was blended and then proceeded through the filter paper. In another control tube, $1 \mathrm{ml}$ of the fermentation fluid was pipetted and $2 \mathrm{ml}$ of cold casein and $5 \mathrm{ml} 5 \%(\mathrm{w} / \mathrm{v})$ TCA were immediately added. The mixture was blended and then proceeded through the filter paper. $2 \mathrm{ml}$ of the filtrate were taken from the test and control tubes and $5 \mathrm{ml}$ of $6 \%(\mathrm{w} / \mathrm{v}) \mathrm{Na}_{2} \mathrm{CO}_{3}$ and $1 \mathrm{ml}$ of Folin-Ciocalteu reagent were added. The mixture from the tubes was blended and left at room temperature for $30 \mathrm{~min}$ until the blue color was developed. In a separate tube (blank), $1 \mathrm{ml}$ of distilled water was measured instead of tyrosine and all other ingredients were added. The absorbance value was read on the spectrophotometer at $660 \mathrm{~nm}$.

To determine the amount of tyrosine, constructing a standard curve was required. It was necessary to make a $1.1 \times 10^{-3} \mathrm{~mol} / \mathrm{l}$ standard tyrosine solution (prepare it in $100 \mathrm{ml}$ of deionized water and heat carefully until it is dissolved and cooled at room temperature). 0.05 , $0.10,0.20,0.30,0.40,0.60$, and $0.60 \mathrm{ml}$ of a standard solution of tyrosine were measured into six tubes and the tubes were supplemented with distilled water to the volume of $2 \mathrm{ml}$. As a blank standard, $2 \mathrm{ml}$ of water were taken. All tubes were incubated at $37^{\circ} \mathrm{C}$ for 10 minutes, and a further procedure was the same as the one for the determination of proteolytic enzyme activity. After constructing a standard tyrosine curve, the tyrosine absorber values contained in the sample filtrate (a) and the control filtrate (b) should be inserted.

Unit of enzymatic activity:

$$
\mathrm{IU} / \mathrm{ml}=\frac{(\mu \mathrm{mol} \text { tyrosine })(8)(\mathrm{df})}{(1)(10)(2)}
$$

where 8 - total sample volume $(\mathrm{ml}), 10$ - incubation time of the sample (min), 1 - volume of enzymes $(\mathrm{ml}), 2$ - volume taken for colorimetric determination $(\mathrm{ml})$, df - dilution factor.

\section{Determination of a-amylase activity}

Invertase enzyme activity was determined using the Bernfeld method (BERNFELD, $1955)$ with modifications. The activity of $\alpha$-amylase in the fermentation liquid was determined by the preparation of a reaction mixture containing $0.5 \mathrm{ml}$ of crude enzyme 
extract, $1.5 \mathrm{ml}$ of buffer ( $\mathrm{pH}$ 6.9) $(20 \mathrm{mmol}$ sodium phosphate and $6.7 \mathrm{mmol} \mathrm{NaCl})$ and $1 \mathrm{ml}$ of $1 \%(\mathrm{w} / \mathrm{v})$ starch. The contents of the tube (sample) were mixed and incubated in a water bath at $37^{\circ} \mathrm{C}$ for $15 \mathrm{~min}$. In the second control tube, all the ingredients were added as in the test tube and the tube was placed in ice until the incubation of the test tube was completed. 1 $\mathrm{ml}$ of the contents of both tubes were taken and $1 \mathrm{ml}$ of dinitrosalicyl reagent (5.3 M K-Natartrate and $96 \mathrm{mmol}$ of 3,5-dinitrosalicylic acid) was added. The test tubes were incubated at $100^{\circ} \mathrm{C}$ for $15 \mathrm{~min}$. The tubes were cooled to room temperature and then the absorbance was spectrophotometrically read at $540 \mathrm{~nm}$.

In order to construct a standard curve, a $0.2 \%$ maltose solution $(2 \mathrm{mg} / \mathrm{ml}$ solution of D - (+) - maltose standard (Sigma Aldrich)) should be made. $2 \mathrm{ml}$ of the final concentration of standard were added to each of the eight tubes: $0.10,0.20,0.30,0.40,0.50,0.60,0.70$, and $0.80 \mathrm{mg} / \mathrm{ml} .2 \mathrm{ml}$ of distilled water should be taken as a blank instead of the standard. Then, 1 $\mathrm{ml}$ of the dinitrosalicylic reagent was added to each tube. The contents of the tubes were carefully mixed and incubated at $100^{\circ} \mathrm{C}$ for $15 \mathrm{~min}$. The tubes were cooled at room temperature and the absorbance was read at $540 \mathrm{~nm}$. Based on the obtained absorbance and known concentration of standards, the standard curve was constructed and the amount of reducing sugar in the sample was determined from it. The enzyme activity unit determines the following formula:

Unit of enzymatic activity: $\mathrm{IU} / \mathrm{ml}=[(\mu \mathrm{mol}$ maltose $) \times 3 \times \mathrm{df}] /(0.5 \times 15 \times 1)$

where 3 - total sample volume $(\mathrm{ml}), 15$-incubation time of the sample (min), 0.5 - volume of enzyme extract $(\mathrm{ml}), 1$-volume of the sample taken for colorimetric detection $(\mathrm{ml})$.

\section{Determination of total protein amount}

The total amount of protein in the fermentation liquid was determined using the Bradford method (BRADFORD, 1976). The method is based on the creation of a complex between the color of Brilliant Blue G. and the protein in solution. The color intensity is proportional to the amount of protein in the solution. In order to determine the amount of protein in the sample, a standard curve for the BSA initial concentration of $1 \mathrm{mg} / \mathrm{ml}$ should be prepared. In each of the ten tubes, $0.1 \mathrm{ml}$ of the final concentration standards: $0.10,0.20$, $0.30,0.40,0.50,0.60,0.70,0.80,0.90$, and $1.00 \mathrm{mg} / \mathrm{ml}$ should be pipetted. The blank tube contains $0.1 \mathrm{ml}$ of distilled water instead of standard. $3 \mathrm{ml}$ of Bradford's reagent were added to all tubes and then mixed slightly. The tubes were left to incubate at room temperature for $30 \mathrm{~min}$. After the incubation was finished, the absorbance was read at $595 \mathrm{~nm}$ using a spectrophotometer. Based on the values of the standards of known concentrations and the resulting absorbances, the standard curve was constructed.

\section{Data analysis}

Paired samples T-test was used for comparing the amount of enzyme in TSB and MH, while Spearman correlation coefficient was used for comparing the amount of proteins and proteases at two broths, via IBM SPSS Statistics 20.

\section{RESULTS AND DISCUSSION}

\section{The total amount of protein}

The total amount of protein in the substrates was measured. The higher concentration of proteins was measured in TSB than in MH. The highest absorbance was measured in the TSB where the isolates E. coli KGPMF 14, E. coli KGPMF 16, E. coli KGPMF 24, E. coli 
KGPMF 21 and Serratia odorifera KGPMF 18 were cultivated. The absorbance of the measured proteins was higher in the MH containing Serratia marcescens biogp 1 KGPMF 19, $K$. pneumoniae KGPMF 11, K. oxitoca KGPMF 1, K. oxytoca KGPMF 2, K. ornithinolytica KGPMF 8. Similar absorbances in TSB and MH were measured in the case of $K$. oxytoca isolates KGPMF 3, K. oxytoca KGPMF 7, K. pneumoniae KGPMF 10, K. pneumoniae KGPMF 12 (Tab. 1).

Table 1. Protease activity and the total amount of protein.

\begin{tabular}{lcccc}
\hline \multirow{2}{*}{ Species } & \multicolumn{3}{c}{ Protease (IU/ml) } & \multicolumn{2}{c}{ Total proteins (mg/ml) } \\
\cline { 2 - 5 } K. oxitoca KGPMF 1 & TSB & MH & TSB & MH \\
\hline K. oxytoca KGPMF 2 & 0 & 0 & 0.02 & 0.13 \\
K. oxytoca KGPMF 3 & 6.1 & 0 & 0.02 & 0.03 \\
K. oxytoca KGPMF 7 & 0 & 0 & 0.02 & 0.02 \\
K. ornithinolytica KGPMF 8 & 1.4 & 0.4 & 0 & 0 \\
K. pneumoniae KGPMF 10 & 0.8 & 0.4 & 0.01 & 0.02 \\
K. pneumoniae KGPMF 11 & 1.5 & 1.4 & 0.01 & 0.01 \\
K. pneumoniae KGPMF 12 & 0 & 5.1 & 0 & 0.03 \\
E. coli KGPMF 14 & 4.3 & 2.2 & 0.02 & 0.0 \\
E. coli KGPMF 16 & 1.6 & 9.5 & 0.07 & 0 \\
E. coli KGPMF 21 & 2.1 & 0 & 0.10 & 0.02 \\
E. coli KGPMF 24 & 1.5 & 0 & 0.12 & 0 \\
S. odorifera KGPMF 18 & 3.9 & 3.6 & 0.12 & 0.06 \\
S. marcescens biogp 1 KGPMF 19 & 1.5 & 0 & 0.03 & 0.0 \\
\hline
\end{tabular}

\section{The protease activity}

Protease activity was higher in TSB than MH. The highest absorbances were measured in the broth where the isolates of E. coli KGPMF 16, E. coli KGPMF 21, E. coli KGPMF 24, S. marcescens biogp 1 KGPMF 19, K. oxytoca KGPMF 2, K. oxytoca KGPMF 7, $K$. oxytoca KGPMF 8, K. pneumoniae KGPMF 12 were cultivated. Protease activity of E. coli KGPMF 14 and $K$. pneumoniae KGPMF 10 was higher in MH. Extracellular protease of $K$. oxitoca KGPMF 1, K. oxitoca KGPMF 3 was inactive in both broths (Tab. 1). A statistically significant correlation between the amount of protein and protease activity in TSB (Spearman correlation coefficient - P <0.05) was obtained, while in MH it was not noticed.

\section{The acid and alkaline invertase activity}

The acid invertase activity was higher in $\mathrm{MH}$ for most of the tested bacteria (E. coli KGPMF 14, E. coli KGPMF 21, E. coli KGPMF 24, S. odorifera KGPMF 18, K. oxitoca KGPMF 1, K. oxitoca KGPMF 2, K. pneumoniae KGPMF 10, K. pneumoniae KGPMF 11). For other isolates, the acid invertase activity was higher in TSB, except for $K$. pneumoniae KGPMF 12 where the acid invertase activity was equal in both broths. The alkaline invertase activity of the tested bacteria was not detected (Tab. 2). 
Table 2. The acid and alkaline invertase activity.

\begin{tabular}{lcccc}
\hline \multirow{2}{*}{ Species } & \multicolumn{2}{c}{ Acid invertase (IU/ml) } & \multicolumn{2}{c}{ Alkaline invertase (IU/ml) } \\
\cline { 2 - 5 } K. oxitoca KGPMF 1 & TSB & MH & TSB & MH \\
K. oxytoca KGPMF 2 & 0.01 & 0.09 & 0 & 0 \\
K. oxytoca KGPMF 3 & 0 & 0.05 & 0 & 0 \\
K. oxytoca KGPMF 7 & 0.09 & 0.03 & 0 & 0 \\
K. ornithinolytica KGPMF 8 & 0.62 & 0.03 & 0 & 0 \\
K. pneumoniae KGPMF 10 & 0.63 & 0.09 & 0 & 0 \\
K. pneumoniae KGPMF 11 & 0.03 & 0.04 & 0 & 0 \\
K. pneumoniae KGPMF 12 & 0.01 & 0.02 & 0 & 0 \\
E. coli KGPMF 14 & 0.09 & 0.09 & 0 & 0 \\
E. coli KGPMF 16 & 0.01 & 0.02 & 0 & 0 \\
E. coli KGPMF 21 & 0.25 & 0.02 & 0.01 & 0 \\
E. coli KGPMF 24 & 0.04 & 0.1 & 0 & 0 \\
S. odorifera KGPMF 18 & 0.01 & 0.1 & 0 & 0 \\
S. marcescens biogp 1 KGPMF 19 & 0.09 & 0.75 & 0 & 0 \\
\hline
\end{tabular}

The amylase activity

The amylase activity was higher for isolates which were grown in TSB, except $E$. coli KGPMF 14, S. marcescens biogp 1 KGPMF 19, K. oxitoca KGPMF 3, K. pneumoniae KGPMF 10, K. ornithinolytica KGPMF 8, wherein the amylase activity was higher in MH. The amylase activity of K. pneumoniae KGPMF 12 was equal in both broths (Tab. 3).

Table 3. Amylase activity and alkaline phosphatase activity.

\begin{tabular}{lcccc}
\hline & \multicolumn{3}{c}{ Amylase (IU/ml) } & \multicolumn{2}{c}{ Alkaline phosphatase (IU/mI) } \\
\cline { 2 - 5 } Species & TSB & MH & TSB & MH \\
\hline K. oxitoca KGPMF 1 & 0.25 & 0.06 & 0.10 & 0.01 \\
K. oxytoca KGPMF 2 & 0.04 & 0.02 & 0.10 & 0.08 \\
K. oxytoca KGPMF 3 & 0.05 & 0.07 & 0.09 & 0.05 \\
K. oxytoca KGPMF 7 & 0.23 & 0 & 0.85 & 0.05 \\
K. ornithinolytica KGPMF 8 & 0 & 0.05 & 0 & 0.00 \\
K. pneumoniae KGPMF 10 & 0.03 & 0.07 & 0 & 0.00 \\
K. pneumoniae KGPMF 11 & 0.22 & 0 & 0.45 & 0.05 \\
K. pneumoniae KGPMF 12 & 0.03 & 0.03 & 0.50 & 0.04 \\
E. coli KGPMF 14 & 0.02 & 0.03 & 0 & 0.04 \\
E. coli KGPMF 16 & 0.08 & 0.07 & 0.08 & 0.06 \\
E. coli KGPMF 21 & 0.09 & 0.06 & 0.05 & 0.04 \\
E. coli KGPMF 24 & 0.26 & 0.20 & 0.11 & 0.05 \\
S. odorifera KGPMF 18 & 0.04 & 0.02 & 0.07 & 0.03 \\
S. marcescens biogp 1 KGPMF 19 & 0 & 0.03 & 0.11 & 0.01 \\
\hline
\end{tabular}

\section{The alkaline phosphatase activity}

The alkaline phosphatase activity was higher in TSB for all tested isolate except $E$. coli KGPMF 14, where alkaline phosphatase was active in MH. Alkaline phosphatase of $K$. 
pneumoniae KGPMF 10 and $K$. ornithinolytica KGPMF 8 was inactive in both broths (Tab. $3)$.

In this paper, the activity of extracellular enzymes of bacteria isolated from cheese made in a traditional way was measured for the first time. By measuring extracellular enzymes, using specific methods, it could be concluded that the activity of extracellular enzymes depended on the type of broth (statistically significant difference in alkaline phosphatase activity in TSB than $\mathrm{MH}, \mathrm{P}<0.05$ ) and the type of bacteria. Based on the screening method, isolates from cheese belonging to the collection of microbiology laboratory of the Faculty of Science, University of Kragujevac (KGPMF), from the genus Escherichia and Klebsiella, except $K$. oxytoca KGPMF 1, did not possess proteolytic and lipolytic activities. S. odorifera KGPMF 18 and S. marcescens biogp 1 KGPMF 19 exhibited lipolytic activity (MLADENOVIĆ et al., 2018a). Bacteria from the spring collection, belonging to the genus Escherichia demonstrated no proteolytic or lipolytic activity. Bacteria isolated from Sokobanja cheese mostly did not manifest proteolytic and lipolytic activity. Their activity was presumably controlled or inhibited since lactic acid bacteria could develop a low $\mathrm{pH}$, which was responsible for the sour taste of cheese. The results of the study from MURUZOVIC et al. (2018) demonstrated the potential of lactic acid bacteria to influence antagonistically the growth of enterobacteria.

Microbial enzymes have been used in various fields, such as chemical, agricultural, and biopharmaceutical industries. Useful enzymes have been expressed in bacteria $E$. coli, Bacillus, and lactic acid bacteria (LIU et al., 2013). Lipase producing microorganisms that belonging fam. Enterobacteriaceae were isolated from the salt pan area of Vaippar, Thoothukudi District, Tamil Nadu, India (KAMALADEVI et al., 2014).

According to WHITAKER (1992) and AVENDAÑo et al. (2016), enzymes play a very important role in food quality. During production, they affect maturation, color, texture, flavor, and nutritional changes. They were mainly used in the food industry to optimize the process, improve the efficiency, quality, shelf life and, most importantly, to achieve the desired organoleptic characteristics of the final product (AVENDAÑo et al., 2016). Acid proteases, like chymosin, were used as coagulants in cheese making. Chymosin represents around 20-30\% of milk coagulants which are used worldwide (SIMPSON et al., 2012; HAERTLÉ et al., 2016). Proteinases favor cheese ripening by accelerating protein hydrolysis, which is a crucial biochemical factor at this stage and has a high impact on texture and flavor. Additionally, peptidases are used to remove bitterness produced by proteinases during ripening (AZARNIA et al., 2010; SANDRI et al., 2011).

Lipases were used for the development of specific flavors. These enzymes hydrolyze short-chain fatty acids, thus decreasing the formation of trans-fatty acids (SANCHEZ and Demain, 2011; TeH et al., 2014; ANOBOM et al., 2014; SAXENA, 2015; SPOHNER et al., 2015; HMIDET et al., 2015) and obtaining about 15-30 times more flavor than traditional process (AZARNIA et al., 2010). Types of cheese depend on the process of ripening, which provides characteristic textures and aromas (HOUDE et al., 2004; ARAVINDAN et al., 2007). In ripening, lipases play a major role in the hydrolysis of triglycerides, diglycerides, monoglycerides, fatty acids, and glycerol to free fatty acids, which are responsible for the characteristic flavor development (HOUDE et al., 2004; AZARNIA et al., 2006; ARAVINDAN et al., 2007). The ripening process including lipases was about 2 to 5 times faster than without it (AZARNIA et al., 2006). However, it is important to optimize the amount of added enzymes and their enzymatic activity, since high levels of lipases could lead to rancidity and reduction in yield (Houde et al., 2004; ARAVINDAN et al., 2007; AZARNIA et al., 2010; TEH et al., 2014; SPOHNER et al., 2015).

The cheese investigated in our study was produced in countryside households around Sokobanja (Southeastern Serbia) from fresh, processed, and unpasteurized cow's milk by using a traditional method. Bacteria penetrated the cheese, presumably, during the production 
or storage. It was assumed that poor hygiene and unpasteurized cow's milk caused the appearance of enterobacteria. Detection of enzyme activity of the isolates was crucial since the bacteria in a changing natural environment demonstrated the potential of becoming a good producer of extracellular enzymes. In our research, it was shown that the substrate, in our case two different broths, affected differently the production of enzymes of isolates.

Microbial enzymes have contributed to the development and growth of the food industry, especially to the optimization process and efficiency. They have also contributed to the improvement of organoleptic characteristics, nutritive value, quality, conservation, and shelf life of the product. The important role of enzymes in monitoring and quality control of the process and products is significant in various sectors of the food industry such as dairy, meat, baking, etc. (AVENDAÑo et al., 2016).

Bacteria from the fam. Enterobacteriaceae syntheses proteolytic and lipolytic enzymes which are responsible for the deterioration of milk and dairy products (ZAJÁC et al., 2015; MASIELLO et al., 2016). In the production of cheese, these enzymes destabilize casein and may modify or even prevent milk coagulation, which could directly affect the formation of the product (CALDERA et al., 2015). Another major problem is that these bacteria can significantly affect color, odor, taste, and texture (CALDERA et al., 2015; BÖHME et al., 2011). Lipolysis may lead to a process called hydrolytic rancidity, where the product develops sour taste and an unpleasant smell (CARPINÉ et al., 2010; KREWINKEL et al., 2016). MASIELlO et al. (2016) isolated lipolytic representatives of the Enterobacteriaceae family (genera Serratia) from pasteurized milk samples which could lead to milk spoilage. According to TRMČIĆ et al. (2016), coliform detection in cheese was associated with specific cheese characteristics, but there was no connection to pathogen detection.

Bacteria from the fam. Enterobacteriaceae were detected in cheese from Sokobanja and demonstrated enzyme activity. The presence of enterobacteria was not desirable, from the aspect of the sanitary safety of the product. The cheese is safe for consumption since it contained a higher concentration of salt which was added during cheese production. Salt was a good preservative and prevented the growth and development of conditionally pathogenic bacteria. Consequently, the number and all the activities, such as enzyme activity of the bacteria, were controlled. Only in the case when bacteria were found out of their natural habitat (cheese with high salt concentration), they can develop enzyme activity (production of extracellular enzymes).

\section{Acknowledgments}

This work was supported by the Serbian Ministry of Education, Science and Technological Development (Agreement No. 451-03-2824/2019-14/2).

\section{References:}

[1] AlemU, F. (2015): Isolation and Screening of Protease Enzyme Producing Bacteria from Cheese at Dilla University, Ethiopia. International Journal of Nutrition and Food Sciences 4 (2): 234-239. doi: 10.11648/j.ijnfs.20150402.25.

[2] AlLEN, R.J.L. (1940): The estimation of phosphorus. Biochemical Journal 34 (6): 858865. doi: 10.1042/bj0340858.

[3] Anobom, C.D., Pinheiro, A.S., De-Andrade, R.A., Aguieiras, E.C., Andrade, G.C., MourA, M., FrEIRE, D.M. (2014): From structure to catalysis: recent developments in 
the biotechnological applications of lipases. BioMed Research International 1-11. doi: $10.1155 / 2014 / 684506$.

[4] Anson, M.L. (1938): The estimation of pepsin, trypsin, papain, and cathepsin with hemoglobin. Journal of General Physiology 20 (1): 79-89. doi: 10.1085/jgp.22.1.79

[5] Aravindan, R., Anbumathi, P., ViruthagiRI, T. (2007): Lipase applications in food industry. Indian Journal of Biotechnology 6: 141-158.

[6] Avendaño, K.A., Anguiano, M., LóPez, E.C., Montañez, L.E., Sifuentes, L., And Balagurusamy, N. (2016): Microbial enzymes applications in food processing. Agro Food Industry Hi Tech 27 (4): 1-63.

[7] Azarnia, S., Lee, B. H., Yaylayan, V., And Kilcawley, K. N. (2010): Proteolysis development in enzyme-modified Cheddar cheese using natural and recombinant enzymes of Lactobacillus rhamnosus S93. Food Chemistry 120 (1): 174-178. doi: 10.1016/j.foodchem.2009.10.003

[8] Azarnia, S., Robert, N., Lee, B. (2006): Biotechnological methods to accelerate Cheddar cheese ripening. Critical Reviews in Biotechnology 26 (3): 121-143. doi: $10.1080 / 07388550600840525$.

[9] Bernfeld, P. (1955): Amylase $\alpha$ and $\beta$. Methods in Enzymology 1: 149-158. doi: 10.1016/0076-6879(55)01021-5.

[10] Böhme, K., Fernández-No, I.C., Barros-Velázquez, J., Gallardo, J.M., CaloMATA, P., CAÑAS, B. (2011): Species identification of food spoilage and pathogenic bacteria by MALDI-TOF mass fingerprinting. Journal of Proteome Research 9: 31693183. doi: $10.5772 / 33884$.

[11] BRADFORD, M.M. (1976): A rapid and sensitive method for the quantitation of microgram quantities of protein utilizing the principle of protein-dye binding. Analytical Biochemisty 72: 248-254. doi: 10.1006/abio.1976.9999.

[12] Caldera, L., Arioli, S., Stuknyte, M., Scarpellini, M., Franzetti, L. (2015): Setup of a rapid method to distinguish among dead, alive, and viable but not cultivable cells of Pseudomonas spp. in mozzarella cheese. Journal of Dairy Science 98 (12): 8368-8374. doi: 10.3168/jds.2015-9677.

[13] Carpiné, D., Dagostin, J.L.A., Santa, H.S.D., Alvarez, D.C., Terra, N.N., Santa, O.R.D. (2010): Atividade proteolítica e lipolítica de bactérias lácticas isoladas de salames artesanais. Ambiência 6: 125-132.

[14] Eisele, B.I., RASChED, R., WALlenfels, K. (1972): Molecular Characterization of Pullulanase from Aerobacter aerogenes. European Journal of Biochemistry 26 (1): 6267. doi: 10.1111/j.1432-1033. 1972.tb01739.x

[15] Haertlé, T. (2016): Enzymes: Analysis and Food Processing. In The Encyclopedia of Food and Health, Caballero, B., Finglas, P., and Toldrá, F., Ed., Academic Press, Oxford.

[16] Hervert, C.J., MARTin, N.H., BoOR, K.J., WiEdMANN, M. (2017): Survival and detection of coliforms, Enterobacteriaceae, and gram-negative bacteria in Greek yogurt. Journal of Dairy Science 100 (2): 950-960. doi: 10.3168/jds.2016-11553.

[17] Hines, D. A., Saurugger, P. N., Ihler, G. M., BenediK, M. J. (1988): Genetic analysis of extracellular proteins of Serratia marcescens. Journal of Bacteriology 170 (9): 41414146. doi: 10.1128/jb.170.9.4141-4146.1988. 
[18] Hmidet, N., NAwANi, N., Ghorbel, S. (2015): Recent development in production and biotechnological application of microbial enzymes. BioMed Research International 1-2. doi: 10.1155/2015/280518.

[19] Houde, A., KAdEMI, A., Leblanc, D. (2004): Lipases and their industrial applications. Applied biochemistry and biotechnology 118 (1-3): 155-170. doi: 10.1385/abab:118:13:155.

[20] Kamaladevi, B., Prabhavathi, P., Sankareswaran, M., Anbalagan, S., RadhaKRISHNAN, N., AND PRABHU, D. (2014): Screening and Medium Optimization of Lipase Producing Bacteria from Saltpan. Research Journal of Chemical and Environmental Sciences 2 (2): 72-77.

[21] Krewinkel, M., Baur, C., Kranz, B., Von Neubeck, M., Wenning, M., Scherer, S., StOECKEl, M., HINRICHS, J., FisCHER, L. (2016): A sensitive and robust method for direct determination of lipolytic activity in natural milk environment. Food Analytical Methods 9 (3): 646-655.

[22] Liu, L., YAng, H., Shin, H., Chen, R.R., Li, J., Du G., ChEN, J. (2013): How to achieve high-level expression of microbial enzymes: strategies and perspectives. Bioengineered 4 (4): 212-223. doi:10.4161/bioe.24761.

[23] Lovett, S. T. (2011): The DNA Exonucleases of Escherichia coli. EcoSal Plus 4 (2): 145. doi: 10.1128/ecosalplus.4.4.7.

[24] Marty, K.B., Williams, C.L., GuynM, L.J., BenediK, M.J., Blanke, S.R. (2002): Characterization of a cytotoxic factor in culture filtrates of Serratia marcescens. Infection and Immunity 70 (3): 1121-1128. doi: 10.1128/iai.70.3.1121-1128.2002.

[25] Masiello, S.N., Martin, N.H., TrmČić, A., Wiedmann, M., Boor, K.J. (2016): Identification and characterization of psychrotolerant coliform bacteria isolated from pasteurized fluid milk. Journal of Dairy Science 99 (1): 130-140. doi: 10.3168/jds.2015-9728.

[26] MiLlER, G.L. (1959): Use of dinitrosalicylic acid reagent for determination of reducing sugar. Analytical Chemistry 31 (3): 426-428. doi: 10.1021/ac60147a030.

[27] Mladenović, K.G., Muruzović, M, Ž., Žugić Petrović, T., Čomić, LJ.R. (2018b): Escherichia coli identification and isolation from traditional cheese produced in Southeastern Serbia. Journal of Food Safety 38 (4): 1-6. doi: 10.1111/jfs.12477.

[28] Mladenović, K.G., Muruzović, M, Ž., Žugić Petrović, T., STEFanović, O.D., Čomić, LJ.R. (2018a): Isolation and identification of Enterobacteriaceae from traditional Serbian cheese and their physiological characteristics. Journal of Food Safety 38 (1): 1-9. doi: $10.1111 /$ jfs. 12387

[29] Muruzovic, M.Z., Mladenovic, K.G., Zugic-Petrovic, T.D., Comic, LJ.R. (2018): Characterization of lactic acid bacteria isolated from traditionally made Serbian Cheese and evaluation of their antagonistic potential against Enterobacteriaceae. Journal of Food Processing and Preservation 42 (4): e13577. doi: 10.1111/jfpp.13577.

[30] Pugsley, A. P., Chapon, C., Schwartz, M. (1986): Extracellular pullulanase of Klebsiella pnumoniae is a lipoprotein. Journal of Bacteriology 166 (3): 1083-1088. doi: 10.1128/jb.166.3.1083-1088.1986.

[31] SANCHEZ, S., DEMAIN, A.L. (2011): Enzymes and Bioconversions of Industrial, Pharmaceutical, and Biotechnological Significance. Organic Process Research \& Development 15 (1): 224-230. doi: 10.1021/op100302x. 
[32] Sanchez-Porro, C., Martin, S., Mellado, E., Ventosa, A. (2003): Diversity of moderately halophilic bacteria producing extracellular hydrolytic enzymes. Journal of Applied Microbiology 94 (2): 295-300. doi: 10.1046/j.1365-2672.2003.01834.x

[33] Sandri, I. G., Fontana, R. C., BarfKnecht, D. M., Da Silveira, M.M. (2011): Application of enzymatic preparations to produce araçá pulp and juice. LWT-food Science and Technology 44 (10): 2217-2222. doi: 10.1590/1678-457X.6381.

[34] SAXENA, S. (2015): Microbial Enzymes and Their Industrial Applications. In: Saxena, S. (Ed.) Applied Microbiology. Springer, India.

[35] Sharma, A., TIWARI, R. (2005): Extracellular enzyme production by environmental strains Serratia spp. isolated from river Narmada. Indian Journal of Biochemistry \& Biophysics 42 (3): 178-181.

[36] Simpson, B.K., RuI, X., XIUJIE, J. (2012): Enzyme-assisted food processing. In: Boye, J.I., Arcand, Y. (eds.) Green Technologies in Food Production and Processing. Springer USA.

[37] Spohner, S.C., Müller, H., Quitmann, H., CzermaK, P. (2015): Expression of enzymes for the usage in food and feed industry with Pichia pastoris. Journal of Biotechnology 202: 118-134. doi: 10.1016/j.jbiotec.2015.01.027.

[38] Sumner, J.B., Howell, S.F. (1935): A method for determination of saccharase activity. Journal of Biological Chemistry 108: 51-54.

[39] Teh, K.H., Flint, S., Palmer, J., Andrewes, P., Bremer, P., Lindsay, D. (2014): Biofilm- An unrecognised source of spoilage enzymes in dairy products. International Dairy Journal 34: 32-40.

[40] Trmčić, A., Chauhan, K., Kent, D.J., Ralyea, R.D., Martin, N.H., BooR, K.J., WiedMANN, M. (2016): Coliform detection in cheese is associated with specific cheese characteristics, but no association was found with pathogen detection. Journal of Dairy Science 99 (8): 6105-6120. doi:10.3168/jds.2016-11112.

[41] WhitaKer, J. R. (1992): Importance of enzymes to value-added quality of foods. Food structure 11 (3): 201-208.

[42] Zajác, P., CAPla, J., Vietoris, V., ZubrickÁ, S., Curlej, J. (2015): Effects of storage on the major constituents of raw milk. Potravinarstvo 9: 375-381. doi: 10.5219/518. 